Research Report No. 39/2010

\title{
Making Space for Grandma: The Emancipation of Traditional Knowledge and the Dominance of Western-Style Intellectual Property Rights Regimes
}

Ikechi Mgbeoji

Osgoode Hall Law School of York University, imgbeoji@osgoode.yorku.ca

Follow this and additional works at: http://digitalcommons.osgoode.yorku.ca/clpe

\section{Recommended Citation}

Mgbeoji, Ikechi, "Making Space for Grandma: The Emancipation of Traditional Knowledge and the Dominance of Western-Style Intellectual Property Rights Regimes" (2010). Comparative Research in Law \& Political Economy. Research Paper No. 39/2010.

http://digitalcommons.osgoode.yorku.ca/clpe/106 


\section{OSGOODE}

OSCOODE HALL LAW SCHOOL

YORK U NIVERSITY

\section{OSGOODE HALL LAW SCHOOL}

Comparative Research in Law \& Political Economy

RESEARCH PAPER SERIES

Research Paper No. 39/2010

Making Space for Grandma: The Emancipation of Traditional Knowledge and the Dominance of Western-Style Intellectual Property Rights Regimes

Ikechi Mgbeoji

\section{Editors:}

Peer Zumbansen (Osgoode Hall Law School, Toronto, Director, Comparative Research in Law and Political Economy) John W. Cioffi (University of California at Riverside) Lisa Philipps (Osgoode Hall Law School, Associate Dean Research)

Nassim Nasser (Osgoode Hall Law School, Toronto, Production Editor) 
CLPE Research Paper 39/2010

Vol. 06 No. 9 (2010)

Ikechi Mgbeogi

\title{
Making Space for Grandma: The Emancipation of Traditional Knowledge and the Dominance of Western-Style Intellectual Property Rights Regimes
}

\begin{abstract}
The question that this paper seeks to tackle is whether the patent system is of any relevance or pertinence to the search for mechanisms for the protection of traditional knowledge(TK) of the medicinal uses of biodiversity possessed by traditional knowledge practitioners across different parts of the world. Allegations of biopiracy have been made against researchers, bioprospectors and other entities actively scouring indigenous peoples' cornucopia for the next miracle drug. The objective of this paper will be achieved through two main approaches. The first analyzes the historical and philosophical roots of the divide between dominant regimes of intellectual property rights (IPRs) and Traditional Knowledge (TK). As already noted, the patent system is used as the framework for the analysis. The second suggests ways and methodologies by which the divide may be bridged. The analysis concedes that the gaps are quite profound but nonetheless offer policy-makers some leeway and flexibility to protect TK by borrowing some of the features of dominant IPRs regimes. The approach is anchored on a pragmatic acceptance of the fact that dominant regimes are too well-established to be displaced by well-meaning but weak protagonists for purer versions of TK-models.
\end{abstract}

Keywords: Traditional Knowledge, Intellectual Property, Policy, IPRs Regimes.

Jel Classification: K 33, O 34

\author{
Ikechi Mgbeogi \\ Professor of Law \\ Osgoode Hall Law School of York University \\ Email: IkechiMgbeoji@osgoode.yorku.ca
}




\title{
Making Space for Grandma: The Emancipation of Traditional Knowledge and the Dominance of Western-Style Intellectual Property Rights Regimes
}

\author{
Ikechi Mgbeoji
}

\section{OVERVIEW}

One of the most dramatic changes in intellectual property rights (IPRs) circles in the past two decades is the emancipation of traditional knowledge systems from the recesses of scorn and neglect. For more than six centuries, the knowledge systems of colonized and dispossessed peoples across the world have languished as western-styled IPRs system gained prominence, acceptance, and legitimacy regardless of cultural differences. Yet, in the past quarter of a century, traditional knowledge systems, otherwise referred to as TK in this paper have witnessed some degree of positive review, especially in policy instruments of international intellectual property organizations ${ }^{1}$ and in international agreements. ${ }^{2}$

The emergence of TK from the marginal doldrums of disrepute and neglect raises the serious question of how best to manage the relationship between TK and the dominant systems or narratives of intellectual property rights (IPRs). Although there are undeniable similarities between TK such as folklore and IPRs such as copyrights, the philosophical and jurisprudential divide are huge and often, radical. Unlike IPRs which tend to be discrete and narrowly focused on categories of intellectual property, TK systems traverse a wide gamut of life, cultural experiences, epistemologies and empiricisms. Thus TK systems are implicated in ecology, agronomy, agriculture, medicine, animal husbandry, music, story-telling, cloth-weaving, et cetera across several thousands of different cultures and peoples. Without any doubts, TK was not designed to fit with the structure and processes of dominant IPRs. Neither the eligibility criteria nor the juridical processes for articulation and vindication of TK rights can easily fit with dominant IPRs regimes.

As I had observed elsewhere (Mgbeoji, 2006a), given the multitudinous nature and diversity of indigenous knowledge systems, it becomes intellectually risky, if not fraudulent for generalized claims to be made regarding the nature of indigenous knowledge systems. It would be unwise and rash to resolve the question of the relationship between IPRs and TK without first limiting the scope of the inquiry to a specific genre or type of TK. This Chapter therefore limits the scope of the inquiry to the TK systems that pertain to the uses of biological products for medicinal and therapeutic needs. The task of this chapter is to examine ways in which TK related to the use of biodiversity for medicinal and therapeutic needs may be mainstreamed with dominant IPRs, in particular, the patent system.

\footnotetext{
${ }^{*}$ Associate Professor, Osgoode Hall Law School of York University, Toronto.

${ }^{1}$ World Intellectual Property Organization (WIPO) ((1998-1999, Geneva, Switzerland) Draft Report, Fact-Finding Missions on Intellectual Property and Traditional Knowledge, at 28.

${ }^{2}$ See for example, Convention on Biological Diversity, ( done at Rio de Janeiro on 5 June 1992), (entered into force 29 December 1993), reprinted in 31 I.L.M. 818 (1992).
} 
In essence, the question that this paper seeks to tackle is whether the patent system is of any relevance or pertinence to the search for mechanisms for the protection of traditional knowledge of the medicinal uses of biodiversity possessed by traditional knowledge practitioners across different parts of the world. Allegations of biopiracy have been made against researchers, bioprospectors and other entities actively scouring indigenous peoples' cornucopia for the next miracle drug (Mgbeoji, 2006b). The objective of this paper will be achieved through two main approaches. The first analyzes the historical and philosophical roots of the divide between dominant regimes of intellectual property rights (IPRs) and Traditional Knowledge (TK). As already noted, the patent system is used as the framework for the analysis. The second suggests ways and methodologies by which the divide may be bridged. The analysis concedes that the gaps are quite profound but nonetheless offer policy-makers some leeway and flexibility to protect TK by borrowing some of the features of dominant IPRs regimes. The approach is anchored on a pragmatic acceptance of the fact that dominant regimes are too well-established to be displaced by well-meaning but weak protagonists for purer versions of TK-models.

The central argument is that notwithstanding the palpable differences between IPRs and TK, there are feasible ways which policy-makers may deploy to legitimate the status of TK as a veritable template for recognition of the enormous contributions of indigenous and traditional cultures over the ages. The paper concludes with the suggestion that although the institutionalization of global TK-models may seem remote at the international level, the feasibility of such models are much more realistic if pursued by decolonized states at the regional and continental levels. As a short term measure, however, attempts to mainstream TK could be anchored on creative adaptation of what already exists in terms of IPRs regimes.

The paper is divided into three parts. Part 1 traces the origins of the modern patent system. Part 2 outlines and analyzes how the dominant economic and political powers have historically privileged IPRs over TK despite the enormous merits and contributions of the later. In the final chapter, this paper lays out a possible road-map for reconciliation between the two regimes. The article concludes with a suggestion that states would do well to pursue regional initiatives aimed at giving legal effect to indigenous and autochthonous models for protection. Waiting on the global community for support and guidance is neither prudent nor effective.

\section{Part 1: The Shady Origins of the Patent System: From Blackmail to FAME}

Contrary to popular myth, the IPRs regimes we have today are not universal verities (Drahos, 1998), but products of European political economy and history. The contemporary dominance enjoyed by modern IPRs regimes across the globe is a product of the aggressive and often violent conquest and colonization of diverse cultures and societies by European states in the 
past five centuries (Penrose, 1951; Helge, 1956). It is a historical fact that modern IPRs such as copyrights, trademarks, and patents regimes have deep roots in European culture, worldview, and imperial impulses (Lowenstein, 2002). Thus, modern IPRs, often portrayed as universal truths with global genetic makeup are in fact originally local expressions of European thought and philosophy. The diffusion and spread of IPRs regimes from Europe to other parts of the world followed distinct patterns of violence, suppression, and outright dispossession. Therefore, the pre-eminence of Western-styled IPRs is a direct manifestation of the forceful imposition of European economic, political, and cultural ideas on colonized parts of the globe. Very few erstwhile colonized states chose and institutionalized modern IPRs on their own volition.

As a colonial construct and implant, Eurocentric IPRs were part of the cultural, economic, and legal instruments for the control and subordination of colonized peoples and economies (Sagoe, 1992; Sklan, 1978). The colonization of the Americas, the Oceania, Australia, Africa, Asia and other parts of the world was premised on two main grounds, namely, a propaganda of European superiority over colonized peoples (Mgbeoji, ibid) and of course, economic exploitation of the colonized (Lindley, 1969). Although the transplantation of Eurocentric IPRs (Abbott et al,1999) to colonized territories has yielded mixed results in post-colonial states (Mgbeoji, 2007), in the colonial encounter, Eurocentric IPRs successfully crowded out TK in many aspects with baleful consequences (Adewopo, 2002).

With particular reference to patents, the dissonance has been astounding. The patent system is not new to controversy. Tracing its origins to Brunelleschi's "blackmail," (Lippert, 1999) of the medieval Italian City-state of Florence, the patent system has waned and waxed to global fame. As recounted by Bruce William Bugbee, in 1421, Filippo Brunelleschi, the Italian architect and painter, announced his invention of an iron-clad vessel, the "Badalone" which he claimed could carry marble across the lake Arno for the construction of the now famous cathedral of Florence (Bugbee, 1961). ${ }^{3}$ Brunelleschi refused to disclose the "Badalone" to the public. In addition, he rejected the idea of putting the vessel at the service of the city unless he was granted a limited right to an exclusive commercial exploitation of the vessel. Florence yielded to his unprecedented demands and on June 19, 1421, the City issued him the first recorded patent in history. To Brunelleschi's embarrassment, the "Badalone" sank on its inaugural trip and the Florentine patent idea sank with it at least, for a long time.

It would appear that after the Florentine debacle, the concept of patents migrated to Venice where it acquired legislative imprimatur and in addition, substantial refinement. For example, the Venetian patent law of 1474 provided for patent duration of ten years, examination of patent applications for novelty, and punishment for infringement of patent rights (White, 1967). Italian artisans and craftsmen began a process of migration to central and Western Europe (Macleod, 1988). Naturally, they did not leave the concept of patents behind them in

\footnotetext{
${ }^{3}$ Prior to the modern era of serious inroads by the patent system into scientific discourse, open exchange of scientific discoveries and ideas was the norm. As Stephen Brush has noted, "science is the long conversation among members of ...community...the glitter of science to many practitioners is its alternative to pecuniary reward." See Brush, Stephen, (1996: 143 at 149).
} 
Italy; they took the patent concept with them: Netherlands in 1817, Spain in 1820, the Vatican in 1833, Sweden in 1834, Portugal in 1837. Thus, it is fair to say that the modern patent concept owes its original inspiration to the Italian City-States of medieval times. From central Europe, the patent concept spread with European immigrants to North and South America; and by colonialism and diffusion, to the rest of the world.

Akin to the debates on the definitions of TK, certain inferences may be made from the various definitions of patents. First, in spite of several theories on patents, especially, attempts to couch the arguments for and against patents in the discourse of human rights, there is no such thing as a human right to patents. Of course, an argument can be made on the fairness or otherwise of appropriating the intellectual product of another person. But the fact is that a patent is a discretionary grant of a State on an invention which excludes unauthorized persons, for a specified number of years, from making commercial use of a clearly defined and specified invention. ${ }^{4}$

Second, the patent system is anchored on a capitalist worldview of the economy. In recognition of these, particularly, the latter, the patent system, especially in Western societies, is ostensibly designed to recompense investors by its offer of a temporary monopolization of the commercial benefits of a clearly defined invention. Third, the system of patents purports to celebrate creativity or authorship as an individual effort. This approach discounts immense societal contributions and the incremental basis of most inventions.

For TK on the other hand, the crux of the matter here is whether the patent system is inherently universal in its philosophy and if so, whether it offers the best economic incentive for protecting and rewarding inventions in the realms of activities that are peculiarly communal and where innovations occur in an incremental nature, for example, in plant genetic resources. Law, as most jurists have restated, is a mirror of societal values. In other words, does the Eurocentric patent concept reflect non-European values? In resolving these difficult questions, certain factors must be taken into consideration. Primarily, the passage of time and contemporary realities have modified the jurisprudence on property ownership, the social nature of the inventive process, notions of legal personality, et cetera, which underpin the patent system. The crucial task thus is to locate the areas of intractable difference.

The patent system may be malleable (Coulter, 1991; David, 1993) in some respects but the question remains whether decolonized states have the political and economic clout to create doctrinal adaptations that best serve their own peculiar needs and aspirations. Unlike powerful industrialized countries that can at will create new international IPRs regimes from the scratch, ${ }^{5}$

\footnotetext{
${ }^{4}$ Attorney-General v. Adelaide Steamship Co., [1913] Appeal Cases, 781.

${ }^{5}$ For example, when it became obvious to the industrialized states that the existing patent regime could not protect computer chip makers, the Washington Semi-conductor treaty was quickly concluded and ratified. Meanwhile, as Peter Drahos has noted, "...in contrast, the issue of protection for indigenous knowledge has largely remained just that, an issue. See Drahos, Peter, (1997:201)
} 
developing countries lack the economic and political machinery needed to create effective but parallel global regimes on TK. Changes to the imperial order would have to be both incremental and radical (Ewans, 2000). At this stage, the patent system has to be understood vis-à-vis TK to figure how the adaptations may be made.

\section{PART 2: The EuRocentricity Of the PATENT SyStem}

Before examining in relative detail the main doctrinal obstacles to the full-scale adaptation of the patent system to decolonized peoples' needs for appropriate IPRs regimes, it is imperative that the social and institutional biases against traditional knowledge in general be addressed. The first socio-cultural obstacle is the notion that bio-cultural knowledge is common knowledge possessed by all traditional and indigenous peoples. First, however, a working definition of TK would be in order. ${ }^{6}$ It must be clarified at the outset that the notion of traditional knowledge as an antiquated and inferior body of knowledge is clearly rejected.

A definition of TK cannot be done (Stenson et al, 1999) outside the context of the provisions of the CBD, Article 27 (3) of the TRIPs Agreement ${ }^{7}$, and perhaps, other international instruments such as Food and Agriculture (FAO) Undertaking of 1983, and various ILO instruments. These instruments and many others rightly locate TK within the context of traditional and indigenous peoples' historical quest for cultural, political, and economic self-determination (Kloppenberg, 1988). The debate on the proper definition of TK is thus inherently complex, recondite and cuts across issues that implicate indigenous peoples' diverse approaches to the philosophical and ethical dimensions of property and personhood.

Further, in addressing this question, two misconceptions on the "traditionality" of TK deserve attention. First, references to the innovations and knowledge of traditional societies, especially on the issue of biological resources as "traditional" are often misconstrued to imply or mean that such inventions and innovations are static, antiquated, and wrapped in mythology. There is a pervasive but unfounded notion that TK is anti-intellectual and a relic of a by-gone era handed down to modern successors via unreliable oral history. As the Four Directions Council points out,

[W] hat is 'traditional' about traditional knowledge is not its antiquity but the way it is acquired and used. In other words, the social process of learning and acquiring which is unique to each indigenous group, lies at the heart of its 'traditionality.' Much of this knowledge is actually quite new, but it has a social meaning and legal character, entirely unlike the knowledge indigenous people acquire from settlers and industrialized societies. (Dutfield; Brush, 1996 [Emphasis added])

\footnotetext{
${ }^{6}$ On indigenous peoples, see The International Labour Organization Convention 169 Concerning Indigenous and Tribal Peoples in Independent Countries, (7 June 1989), reprinted in 28 I.L.M. 1382; Commission on Human Rights, Preliminary Report on the Study of the Problem of Discrimination Against Indigenous Populations, UN Doc.E/CN.4/sub.2/L.566 [1972]; Chapter 2 paragraph 34, UN Declaration of the Rights of Indigenous Peoples, UN. Doc. E/CN.4/1995/2, reprinted in 34 I.L.M. 541 (1995); Wolfrun, Rudiger , (1999), The Protection of Indigenous Peoples in International Law, Zaorv-Heidelberg Journal of International Law, 59: 369.

${ }^{7}$ The literature on this burgeoning school of thought is quite remarkable. See generally, Greaves, Tom, ed., (1994).
} 
The second common misconception about TK is that traditional knowledge of biological resources are mere discoveries of "natural phenomena." As Gurdial Nijar (1996)points out,

[T]traditional uses, although based on natural products, are not 'found in nature'; as such. They are products of human knowledge. To transform a plant into a medicine, for example, one has to know the correct species, its location, the proper time of collection (some plants are poisonous in certain seasons), the part to be used, how to prepare it (fresh, dried, cut in small pieces, alcohol, the addition of salt, etc.), the way to prepare it (time and conditions to be left in the solvent). And finally the posology (route of administration and dosage.)

From the foregoing, it may be posited that TK refers to that body of knowledge, practices, innovations of traditional peoples regulating the ways by which knowledge is acquired, practiced, transferred, and shared among a given peoples in their traditional setting. The scientific merits of TK have been astounding (Isaac, 1970). Over the millennia, small-scale farmers and local peoples have contributed to plant diversity by breeding assorted crop varieties to suit particular local conditions (Friends of the Earth, 1995; Johnson, 1992: 2). ${ }^{8}$ For instance, Indian farmers have grown over 30,000 different varieties of rice during the past century. The native Andeans have developed hundreds of species of tomatoes, potato, maize and beans. Indeed, scientists reckon that the "the total genetic changes achieved by farmers over the millennia was [is] far greater than that achieved by the last hundred or two years of more systematic science-based efforts (Shiva, ibid at 259)."

Apart from developing new varieties, the knowledge of biological resources for medicinal and other uses by local farmers and healers are often phenomenal and pragmatic. For example, in Sierra Leone, local farmers can differentiate between 70 different varieties of rice based on several criteria including: length to maturity, ease of husking, proportion of husk to grain size and weight, susceptibility to insect attack, behaviour in different soils and moisture levels, cooking time and qualities (Nijar, 1994:17).

TK is not merely of academic or theoretical importance; it often serves practical ends. For instance, in Rwanda, farmers have cultivated mixtures of beans that perform better in their poor soil conditions. The Aguarana Jivaro community in the Peruvian Amazon has developed 61 distinct cultivars of cassava and in the Philippines 123 rice varieties have been found at just five sites. In both cases, the varieties are designed to suit certain specific requirements and needs. Thus, the abundance of multitudinous varieties and species of plant resources and the knowledge of the uses thereof among traditional societies are not merely dependent upon

\footnotetext{
${ }^{8}$ Traditional ecological knowledge may be defined as "a body of knowledge built by a group of people through generations living in close contact with nature. It includes a system of classification, as set of empirical observations about the local environment, and as a system of selfmanagement that governs resource use."
} 
geographical quirks but partly a result of deliberate and cumulative intellectual efforts spanning thousands of years. In order to achieve these sophisticated results in the improvement of plant varieties or cultivars, it has been observed that those farmers:

[E]mploy taxonomic systems, encourage introgression, use selection, make efforts to see that varieties are adopted, multiply seeds, field test, record data and name varieties [and in fact]... do what many Northern plant breeders do (Friends of the Earth, ibid: 4).

According to a report from the World Resources Institute,

[I]ndians dwelling in the Amazon River make use of some 1300 medicinal plants, including antibiotics, abortifacients, contraceptives, anti-diarrheal agents, fungicides, anesthetics, muscle-relaxants, and many other most of which has not been investigated by researchers (Panjabi, 1993; Scalise and Nugent, 1995; Merges, 1998).

Seventy-four per cent of the pharmacologically active trees reported by an indigenous group correlated with laboratory tests whereas in contrast only 8 per cent of random samplings showed any activity. In short, absent "the aid of indigenous groups, it is estimated that for every commercially-successful drug, at least five thousand species must be tested (Jenks, 1995)." Michael Ballick of the New York Botanical Gardens found that using traditional knowledge increased the efficiency of screening plants for medicinal properties by more than four hundred per cent (Nijar, ibid). It is therefore no coincidence that a decisive number of drugs derived from plant resources have been with the help of local peoples operating outside the dominant Western framework of what constitutes "scientific knowledge (Roht-Arriaza, 1996).

Modern international law has equally come to terms with the reality of traditional input into the improvement, conservation and diversification of biological resources. ${ }^{9}$ The preamble of the CBD recognizes the "close and traditional dependence of many indigenous and local communities embodying traditional lifestyles on biological resources." ${ }^{10}$ Article 10 (c) of the CBD obliges Contracting Parties to "protect and encourage customary use of biological resources in accordance with cultural practices that are compatible with conservation or sustainable use requirements." ${ }^{11}$ Similar recognition is embodied in Article 8 (j) of the CBD which obliges Contracting Parties to:

$[R]$ espect, preserve and maintain knowledge, innovations and practices of indigenous and local communities embodying traditional lifestyles relevant for the conservation and sustainable use of biological diversity and their wider application with the approval and involvement of the holders of such knowledge, innovations and practices and encourage the equitable sharing of the benefits arising from the utilization of such knowledge, innovations and practices. ${ }^{12}$

\footnotetext{
${ }^{9}$ Preamble, Convention on Biological Diversity, supra note 2.

${ }^{10} / d$.

${ }^{11}$ Id.

${ }^{12}$ Article 8 (j) of the CBD, id.
} 
The salient points from analyses above are that the links between rational human impact on and mutual interaction with plant resources is enormous and profound. Further, the notion that biological resources in the gene-rich countries are necessarily of a "wild" character devoid of human input is often generalized and exaggerated. A considerable portion of the so-called wild biological resources and ecosystems are in fact products of centuries of human impact on the ecosystem and particularly, plants (Young, 1990; Hochberg, 1996; Kaufman and Mallory, 1993). Of course, the mischaracterization of TK as "raw materials" denies and seeks to delegitimize the enormous intellectual contributions made over the centuries by the so-called informal breeders, farmers and other traditional peoples.

Yet, the intellectual feats of innovation by traditional and indigenous peoples wrought within the framework of traditional societies cannot be adequately protected by modern patent law and processes. The question is, why? A close examination of the doctrines of the patent system will illuminate this paradox. For the purposes of securing patent protection on biological resources, for example, it is not enough that an innovation has been wrought. The threshold for legal protection under the patent regime is whether the invention has surpassed obvious or prior art in the field of that invention (De Valoir, 1995; Seay, 1998-9). In attempting to apply patent-like protections to biological resources, the modified test is to ask: when do such innovations, private or collective, surpass obvious knowledge or prior art? (Caillaux, 1994) And whose prior art is relevant?

It seems clear that the opposition by the "scientific and industrial" community to the scientific worth or merit of traditional bio-cultural knowledge has nothing to do with the innate inferiority of the latter but a reflection of a socially constructed relegated status for the epistemology and of innovations arising from the so-called traditional or informal sectors. As the environmental activist Pat Mooney has stridently posited, "the argument that intellectual property is only recognizable when performed in laboratories with white lab coats is fundamentally a racist view of scientific development" (Shiva, 1992). Every bio-cultural innovation, regardless of the cultural framework from which it springs from deserves to be judged on its own merits and not to be peremptorily categorized as "raw material" or automatically elevated to the status of an invention merely because of the respective cultural setting from it is made or derived.

The enduring Eurocentricity of the patent system manifests itself yet again in the fiction that inventions are invariably the result of individual, spontaneous creativity and genius. A mythological but legally sanctioned concept of reward and recompense upon the idea of individual inventiveness discounts the daily reality that most inventions are the result of incremental insights into what already exists in society. In the extremely perverse manifestation of the Eurocentric myth on inventive genius, the "inventive genius" and thus property in the inventions, belongs not to the actual "inventor", but to the capital investment made by a 
multitudinous number of corporate or public stakeholders. This pandering to modern capitalism affords juridical basis for ownership by corporate entities of thousands on inventions. For farmers and native healers in traditional and indigenous societies, the notion that inventorship is a solitary exercise is a juridical and institutional impediment.

The myth of the inventor as a lone ranger leads to the common notion that the patent concept is inter alia, incompatible with the inventive process in traditional and indigenous communities. The communal/collective nature of the development and improvement of bio-cultural knowledge in traditional social structures and units has been posited as one of the grounds why such units of legal persona may not secure patent protection for their intellectual contributions to biological resources (Gana, 1995). This school of thought points to the individualistic structure of Western societies. The contention is that the patent system is partly predicated on the concept of the inventor as an individual and the inventive process itself, as an exercise in solitude (Petersen, 1992; Hannig, 1996). In addition to the obvious generalization inherent in this categorization of the inventive process in non-Western societies, there are problems of misapprehension of the modern social structure of the inventive process in Western societies.

The notion of the solitary Western scientist and inventor in his isolated basement or garage has become a legal anachronism. What baffles the mind is the longevity and obduracy of this myth. Indeed, the contemporary reality is that since the legal fiction of an employer's ownership in the employee's invention, ${ }^{13}$ and the economics-of-scale of group research, a community of scientists working away in huge laboratory complexes has driven the concept of the solitary inventor to virtual extinction. Yet, modern patent law persists to sustain the myth of the individual inventor. As Alfred Kuhn noted in path-breaking treatise,

[T] he transformation of technology and of economic society during the last century negates completely the patent law assumption as to the nature of the inventive process....in the modern research laboratories, tens, hundreds of men focus, upon single, often minute problems; inventions become increasingly inevitable. (Kuhn, 1996)

According to David Safran,

[I]n this age, most inventions result from corporate research efforts...a growing number of these research efforts are the result of the work of several research and development teams that are located in different countries.(Safran, 1983)

Assuming that the hypothesis of a collective inventive process in traditional societies holds, the transformation of the inventive process in Western societies is in several material respects similar to the inventive process in the so-called informal sector. As Stephen Brush notes, "collective invention is a common and determinant force in both local economies and the world economy"(Brush, ibid in footnote.) Interestingly, it has not been suggested such collectively invented products in Western societies cannot be patented because of a perceived inability to

\footnotetext{
${ }^{13}$ In virtually every patent jurisdiction in the world, an employer owns the patent right to an employee's invention if the employer is hired to invent or the invention is made in the course of the employment using his employers' tools. However, under some narrow circumstances, the employee may own the invention. Similarly, governments and its research institutions can own the inventions of its employees. See Vaver, (1997).
} 
pin down the critical "flash of genius" involved in the invention to a member of the collegial team in a Western laboratory. Rather, the patent law has been adjusted in western countries to create a convenient legal fiction of an employer's ownership in the employees' invention and the attendant consequence of reducing the individual inventor to a hired worker.

The inescapable conclusion is that like the "scientists" in the laboratories of the industrialized states who exchange information, collective groups of traditional knowledge holders and practitioners also exchange ideas to resolve and find solutions to deep and complex problems relating to biological resources. As the Crucible Group argued, "farmer's fields and forests are laboratories. Farmers and healers are researchers. Every season is an experiment." ${ }^{14}$ If corporate inventors are honoured with patents, a fortiori, their informal counterparts deserve the same privileges.

Further, just like the modern patent law created the fiction of corporate "creative or inventive" genius to serve social and economic imperatives, non-Western jurisprudence has legal personalities serving same or similar ends. These artificial legal personas or juridical entities are usually designed for the regulation of diverse functions including land ownership, succession, inheritance, et cetera. Indeed, the category of legal persons is not closed. Yet, domestic laws in several decolonized states have largely maintained colonially-inspired categories of legal personalities, thus further enabling the irrelevance of the patent system to local needs and realities.

Another Eurocentric aspect of the patent regime is the conception of what constitutes public domain for the purposes of evaluating novelty. The prevalent notion is that TK is a matter of common knowledge and resides in the public domain. It is argued that this tenet of patent law when uncritically applied to traditional and indigenous settings is flawed on at least, three grounds. First, not all TK is in the public domain. For instance, native healers, in particular, hardly reveal the secrets of their medicinal knowledge and herbal remedies. Secrecy of their knowledge guarantees their power and influence in the local communities. Indeed, the rituals, magic and spirituality which often surrounds the practice of traditional healing is, in addition to their other myriad societal functions, a critical aspect of the "secrecy regimes" (WIPO Report, ibid in footnote) imposed on such bio-cultural knowledge by herbalists and healers.

Second, assuming, but not conceding that all TK is in the public domain, placement of such knowledge in the public domain by overzealous researchers without the consent of native healers, does not ipso facto, extinguish a right of ownership to intellectual property. This principle is the rationale for the regime of prior informed consent (PIC) in contemporary international law on access to traditional and bio-cultural knowledge. Ironically, it is often the same information or knowledge construed to be in the "public domain" in the so-called

\footnotetext{
${ }^{14}$ The Crucible Group, 2000 x-xviii.
} 
traditional societies, which affords the basis for some patents on bio-cultural resources in some other countries, particularly, Japan and the United States. Third, the concept of public domain is an occidental legal principle which should not be foisted on traditional societies without informed consent.

Beyond the problem of what constitutes public domain, another aspect of the problem of novelty is the mistaken assumption by many policy-makers that there is a universal consensus on the concept of novelty as a criterion in granting patents. A careful analysis of international patent law and practice does not support the notion of absolute global novelty in the determination of what constitutes a patentable invention. As the United Nations Conference on Trade and Development (UNCTAD) recently observed, "there is no agreed international standard of absolute novelty and, within limits, member countries may apply the different approaches recognized in domestic patent laws." ${ }^{15}$

In addition to the definitional anarchy on novelty, an international juridical bifurcation arising from the United States and European patent law jurisprudence on novelty and prior art has not yet been bridged. This technical and geographically-relative approach to construing the concept of novelty and prior art is hardly dissimilar to the medieval and eighteenth-century patent policies of the fledgling European industrial States; yet it has legislative force by virtue of section 102 of the United States Patent Act. ${ }^{16}$

Given that innovations in the informal paradigm are largely conducted in traditions where the keeping of formalized data in books is the exception rather than the rule, the seeming triteness of such TK in such societies would not debar such bio-cultural knowledge from being construed as "novel" in another country like the United States (Oddi, 1989). The paradox is that such biocultural knowledge would be ineligible for patent protection in the home country. Hence, what is an obvious invention or prior art in India, as the controversy over Neem derivatives and Turmeric patents demonstrate (Jain, 1999), may be construed as a novel art in the United States of America for the purposes of obtaining a patent grant. Yet, in both cases, the TK were unjustly patented in the United States. Consequently, the blurring of the law on novelty permits, or even encourages some biotechnology and pharmaceutical firms to privatize traditional biocultural knowledge through a cosmetic re-packaging of those resources and knowledge. Thus, it is evident that at the doctrinal level, the ideological values and worldview encoded in the IPRs of the colonizing European powers were often alien to indigenous and traditional peoples ethos and economic traditions (Farley, 1997-98).

\footnotetext{
${ }^{15}$ UNCTAD (1996), The TRIPS Agreement and Developing Countries, Geneva, Switzerland, at 32.

${ }^{16} 35$ U.S.C. 1982. See also, Gratwick, Stephen, (1972), Having Regard to What Was Known and Used, The Law Quarterly Review, 88: 341. Further to the WTO, the United States has amended this section but the amendment limits it only to WTO Member states.
} 


\section{Part 3: Charting the Path of Engagement}

In attempting to apply patent-like protections or other forms of modern IPRs to TK, various jurisprudential hurdles have to be crossed. Some of the issues of jurisprudence pertain to misconceptions and exaggerations on IPRs vis-à-vis indigenous peoples. These include the notion that TK is a body of knowledge in the public domain. The other pertains to the notion that TK knowledge is about the "natural" workings of nature. The implication here is that practitioners off TK merely stumbled on some information without making intellectual inputs in identifying, understanding, organizing, using the knowledge.

While the preceding pages have shown that in many respects TK is incompatible with dominant IPRs, there are equally sound arguments to be made for adapting modern IPRs in some cases to suit the needs of traditional and indigenous peoples. For instance, the category of legal persons could be reconfigured to meet the demands and needs of traditional peoples. Such legal persons as Stools, Families, Kindreds, Clans, Age-grades, the spirits of the unborn, ancestral spirits, and other forms and categories of legal personality which have served traditional societies for millennia can gain juridical recognition. In Brazil, for instance, pursuant to a proposed bill, $\mathrm{PL}^{17}$ N. 2.057, of 23 October 1991, indigenous peoples have legal personality and their legal existence would not depend upon any type of registration or any act of government. Under the proposed legislation, "indigenous communities, or any of their members, have the right to apply for a patent of invention, utility model, industrial model or industrial design which has been developed utilizing their traditional collective knowledge." ${ }^{18}$ Ultimately, the incompatibility of the patent system with TK lies in epistemic schism (Oguamanam, 2006) rather than in the purported areas of antiquity, openness, and stagnation of TK.

While efforts are made to adapt some modern IPRs to accommodate the peculiarities of TK, perhaps it high time decolonized states gave serious thoughts to the proposals for regional initiatives aimed at giving juridical support autochthonous and indigenous legal regimes for the protection of TK. Regions such as Africa, Latin America, et cetera should seriously consider establishing regional protocols for the protection of IPRs. Waiting on the entire global train to join before embarking on the journey could mean a perpetual wait for justice and fairness in the world of IPRs. Indigenous and traditional peoples have been made to wait for far too long.

\section{REFERENCES}

Abbott, F. et al, eds., (1999), The Making of the International Intellectual Property System, The Hague: Kluwer Publications

\footnotetext{
${ }^{17} \mathrm{PL}$ is the acronym for "projeto de Lei" or legislative bill, in English. See also, Stenson \& Gray, ibid.

${ }^{18}$ Art. 19 of PL 2057/91.
} 
Adewopo, Adebambo, (2002), The Global Intellectual Property System and Sub-Saharan Africa: A Prognostic Reflection, University of Toledo Law Review, 33:749.

Barsh, Russell, (1996), Forests, Indigenous Peoples and Biodiversity: Contribution of the Four Directions Council Submission to the Secretariat of the Convention on Biological Diversity.

Brush, Stephen, (1996), Is Common Heritage Outmoded? In Brush, Stephen \& Stabinsky, Doreen, eds., Valuing Local Knowledge-Indigenous People and Intellectual Property Rights, Washington: Island Press.

Bugbee, Bruce Willis, (1961), The Early American Law of Intellectual Property: The Historical Foundations of the United States Patent and Copyright Systems. Unpublished Thesis, University of Michigan, USA, at 76.

Caillaux, Jorge, (1994), Biological Resources and the Convention on Biological Resources" Journal of Environmental Law and Policy in Latin America and the Caribbean, 1: 9 at 10.

Coulter, Moureen, (1991), Property in Ideas: The Patent Question in Mid-Victorian Britain, Missouri: USA: The Thomas Jefferson University Press.

David, Paul A., (1993), Intellectual Property Institutions and the Panda's Thumb: Patents, Copyrights, and Trade Secrets in Economic Theory and History. In Wallerstein, Mitchel B., et al, eds., Global Dimensions of Intellectual Property Rights in Science and Technology, Washington, D.C: National Academy Press: 19-62.

de Valoir, Tamsen, (1995), The Obviousness of Cloning, Intellectual Property Journal, 9: 349

Drahos, P, (1998), The Universality of Intellectual Property Rights: Origins and Development, in Intellectual Property and Human Rights, at 13. Available at:

http://www.wipo.int/tk/en/hr/paneldiscussion/papers/pdf/drahos.pdf [accessed February 15 2009]

Drahos, Peter, (1997), Indigenous Knowledge and the Duties of the Intellectual Property Owners, Intellectual Property Journal, 11: 201

Dutfield, Graham, The Public and Private Domains: Intellectual Property Rights in Traditional Ecological Knowledge, Oxford Electronic Journal of Intellectual Property Rights $<$ http//users.ox.ac.uk/ mast. Accessed on 9/21/99.

Ewens, Lara, (2000), Seeds Wars: Biotechnology, Intellectual Property and the Quest for High Yield Seeds, Boston College International and Comparative Law Review, 23: 285 at 307. 
Farley, C., (1997-1998), Protecting Folklore of Indigenous Peoples: Is Intellectual Property the Answer?' Conn. Law Review, 30: 1-58.

Friends of the Earth, (1995), Intellectual Property Rights and the Biodiversity Convention: The Impact of GATT, Bedfordshire, at 2.

Gana, Ruth L., (1995), Has Creativity Died in the Third World? Some Implications of the Internationalization of Intellectual Property, Denver Journal of International Law and Policy, 24: 109-144.

Gratwick, Stephen, (1972), Having Regard to What Was Known and Used, The Law Quarterly Review, 88: 341.

Greaves, Tom, ed., (1994), Intellectual Property Rights for Indigenous Peoples: A Source Book, Oklahoma: Society for Applied Anthropology.

Grundmann, Helge E., (1976), Foreign Patent Monopolies in Developing Countries: An Empirical Analysis, 12 (2) J. Dev. Stud., 186-196.

Hannig, Mark, (1996), An Examination of the Possibility to Secure Intellectual Property Rights for Plant Genetic Resources Developed by Indigenous People's of the NAFTA States: Domestic Legislation Under the International Convention for New Plant Varieties, Arizona Journal of International and Comparative Law, 13(1): 175-252.

Hochberg, Michael, ed. (1996), Aspects of the Genesis and Maintenance of Biological Diversity, Oxford, England: Oxford University Press.

Isaac, Erich, (1970), Geography of Domestication, Englewood Cliffs, New Jersey: Prentice-Hall.

Jain, Meetali, (1999) Global Trade and the New Millennium: Defining the Scope of Intellectual Property Protection of Plant Genetic Resources and Traditional Knowledge in India, Hastings Int'I \& Comp. L. Rev. 22: 815-16.

Jenks, Daniel, (1995), The Convention on Biological Diversity-An Efficient Framework for the Preservation of Life on Earth?, Northwestern Journal of International Law and Business, 15: 636 at 646.

Johnson, Martha, (1992), Research on Traditional Environmental Knowledge: Its Development and its Role. In Johnson, M. ed., Lore: Capturing Traditional Environmental Knowledge, Ottawa, Canada: IDRC. 
Kaufman, Les \& Mallory, Kenneth, eds., (1993), The Last Extinction, Cambridge, Mass: MIT Press.

Kloppenburg, Jack, (1988), First the Seed: The Political Economy of Plant Biotechnology, 14922000, Cambridge, England: Cambridge University Press.

Kuhn, Alfred, (1996), The Structure of Scientific Revolution, $3^{\text {rd }}$ ed., Chicago, IL: University of Chicago Press.

Lindley, Mark, (1969), The Acquisition and Government Of Backward Territory In International Law: Being A Treatise On The Law And Practice Relating To Colonial Expansion, New York: Negro Universities Press.

Lippert, Owen, (1999), One Trip to the Dentist is Enough-Reasons to Strengthen Intellectual Property Rights Through the Free Trade Area of the Americas Now. In Lippert, Owen, ed., Competitive Strategies for the Protection of Intellectual Properties, Vancouver, British Columbia: The Fraser Institute, 1999: 129.

Lowenstein, J., (2002), The Author's Due: Printing and the Pre-History of Copyright, Chicago, IL:, University of Chicago Press

Macleod, Christine, (1988), Inventing the Industrial Revolution: The English Patent System, 1660-1800, Cambridge, England: Cambridge University Press.

Merges, Robert P., (1988), Intellectual Property in Higher Life Forms: The Patent System and Controversial Technologies, Maryland Law Review, 47: 1051-1075

Mgbeoji, Ikechi (2006), Global Biopiracy: Patents, Plants, and Indigenous Peoples, Vancouver, British Columbia, UBC Press.

Mgbeoji, Ikechi (2006a) Beyond Patents: The Cultural life of Native Healing and the Limitations of the Patent System as a Protective Mechanism for Indigenous on the Medicinal Uses of Plants Canadian Journal of Law and Technology 5:1-12

Mgbeoji, Ikechi, (2007), TRIPS and TRIPS Plus Impacts in Africa. In Daniel Gervais, ed., Strategies to Optimize Economic Development in a TRIPS Plus Era, Oxford, England: Oxford University Press.

Nijar, Gurdial Singh, (1994)Towards a Legal Framework for Protecting Biological Diversity and Community Intellectual Rights- A Third World Perspective, Third World Network Discussion Paper, Penang, Malaysia (On file with the author) at 17.

Nijar, Gurdial, (1996), TRIPS and Biodiversity: The Threat and Responses-A Third World View, Malaysia: Third World Network, at 16 
Oddi, Samuel A., (1989), Beyond Obviousness: Invention Protection in the Twenty-First Century, The American University Law Review, 38: 1097-1148.

Oguamanam, Chidi (2006), International Law and Indigenous Knowledge: intellectual property, plant biodiversity, and traditional medicine, Toronto, Canada: University of Toronto Press

Panjabi, Ranee Kooshie Lal, (1993), International Law and the Preservation of Species: An Analysis of the Convention on Biological Diversity Signed at the Rio Earth Summit, Dickinson Journal of International Law, 11(2): 187-281.

Penrose, E., (1951), The Economics of the International Patent System.

Petersen, Kirstin, (1992), Recent Intellectual Property Trends in Developing Countries, Harvard International Law Journal, 33: 277-290

Roht-Arriaza, Naomi, (1996), Of Seeds and Shamans: The Appropriateness of the Scientific and Technical Knowledge of Indigenous and Local Communities Michigan Journal of International Law, 17: 919-965.

Safran, David, (1983), Protection of Inventions in the Multinational Marketplace: Problems and Pitfalls in Obtaining and Using Patents, North Carolina Journal of International Law and Commercial Regulation, 9(1): 117-132.

Sagoe, Ekua T, (1992), Industrial Property Law in Nigeria, The Comparative Law Yearbook of International Business, 14: 312

Scalise, David G. \& Nugent, Daniel, (1995), International Intellectual Protection for Living Matter: Biotechnology, Multinational Conventions and the Exception for Agriculture, Case Western Reserve Journal of International Law, 27:83-118.

Seay, Nicholas, (1988-9), Protecting the Seeds of Innovation: Patents Plants, A.I.P.L.A Quarterly Journal, Nos. 3\&4: 419

Shiva, Vandana (1992)The Violence of the Green Revolution Delhi, Zed Books.

Sklan, Mark, (1978), African Patent Statutes and Technology Transfer, Case Western Reserve Journal of International Law, 10: 55-66.

Stenson, Anthony \& Gray, Tim, (1999), The Politics of Genetic Resource Control, London, England: Macmillan, [hereinafter Stenson \& Gray]; Anderfelt, Ulf, (1971), International Patent Legislation and Developing Countries, The Hague: Martinus Nijhoff.

Vaver, David, (1997), Intellectual Property, Concord, Ontario, Canada: Irwin Law, 147-149.

White, Lynn, Jr., (1967), Jacopo Acontio as an Engineer, American Historical Review, 72: 432.

Young, John, (1990), Sustaining the Earth, Cambridge, Mass: Harvard University Press. 